\title{
A.I. Кудринська
}

\author{
A.I. Kudryns'ka
}

\section{СОЦІОЛОГІЧНА КОНЦЕПТУАЛІЗАЦІЯ ФЕНОМЕНУ САМОЗАЙНЯТОСТІ НАСЕЛЕННЯ}

\begin{abstract}
The author considers the conceptual principles of the phenomenon of selfemployment of the population in the sociological perspective, its classification by forms and signs, and its meaning for the socio-economic development of Ukraine's society.
\end{abstract}

Розв’язання проблем забезпечення продуктивної зайнятості населення й ефективного розвитку ринку праці актуалізує перегляд підходів до формування державної політики, які б мали сприяти підвищенню ролі самозайнятості, підприємницької та інноваційної діяльності.

Зайнятість виступає інтегральним показником результативності реформ, оскільки акумулює і відображає динаміку і наслідки економічних, соціальних, демографічних процесів. 3 економічного боку зайнятість пов’язується з можливістю людини своєю працею забезпечувати собі і своїй сім'ї гідне існування, сприяючи в той же час зростанню ефективності суспільного виробництва. Соціально-демографічна функція зайнятості полягає у формуванні і розвитку особистості щодо етапів їі життєвого циклу, кар'єрного і статусного зростання [1, с. 111].

Скорочення сукупного попиту на робочу силу, звуження масштабів зайнятості, зниження загального рівня добробуту населення та зростання бідності створюють передумови для розвитку нестандартних форм зайнятості, поширення її різних форм, переорієнтації на більш прибуткові види діяльності, часто на поєднання діяльності в різних секторах економіки.

Соціальні наслідки кожного виду зайнятості визначаються комбінацією особистих (для кожної особи, зайнятої конкретним видом діяльності) та суспільних результатів, пов’язаних з підвищенням добробуту, зниженням (або зростанням) соціальної напруги, зміною масштабів соціальної ізоляції окремих верств населення та маргіналізації суспільства в цілому [2, с. 265].

Сучасний етап розвитку української економіки характеризується появою нових явищ у соціальній сфері та на ринку праці. Розвиток особистості в суспільстві означає постійне розширення можливостей для задоволення ㄲï потреб, а також існування широких можливостей реалізації власних здібностей кожною людиною за вільного вибору своїх цілей, максимального заохочення з боку держави. Це основна ідея людського розвитку. Людський розвиток визначається як процес зростання можливостей, розширення вибору і досягнення певного рівня добробуту [2, с. 26]. 
Зміни в економіці країни знайшли своє відображення й у відповідній сегментації ринку праці, що призвело до зміни складу працюючих, поширення нестандартних форм зайнятості. Зокрема, статистичні дані свідчать про помітне зростання чисельності та питомої ваги самозайнятих, включаючи зайнятих в особистому підсобному селянському господарстві, безоплатно працюючих членів сім'ї.

Аналіз останніх досліджень і публікацій свідчить, що проблему самозайнятості, гносеологічну природу та механізми їі підтримки розглядали у своїх працях вітчизняні вчені О.О. Волик, М.І. Долішній, С.М. Злупко, О.В. Іващенко, Е.М. Лібанова, В.В. Онікієнко, М.М. Пітюлич та ін. 3 наукових досліджень цієї проблематики, а також статистичних даних, можна стверджувати, що в сучасних умовах економічного розвитку самозайнятість $є$ самостійним і важливим елементом регулювання ринку праці. Вона за своїми масштабами і характером здатна певною мірою знімати соціальну напругу у сфері соціально-трудових відносин. Це підтверджується і досвідом країн з розвинутими ринковими відносинами, таких як Греція, Португалія, Іспанія тощо.

Досвід індустріально розвинених країн світу незаперечно показує, що найбільш ефективний шлях досягнення сталого розвитку - послідовне стимулювання економічної активності населення. Це досягається завдяки підтримці різноманітних форм трудової діяльності, включаючи самостійну зайнятість населення.

Дослідницькою метою є розгляд концептуальних засад феномену самозайнятості населення в соціологічній перспективі, iï класифікації за формами та ознаками, а також наслідків для соціально-економічного розвитку українського суспільства.

Самозайнятість населення - специфічна форма економічної діяльності. Її суть полягає в тому, що людина сама знаходить для себе джерело доходів, яке забезпечує їй гідне існування в результаті економічної діяльності, що не суперечить законам країни. Самозайнятість реалізується через конкретні форми включення економічно активного населення в господарську діяльність. На сьогоднішній день - це одна 3 важливих форм адаптації до нових відносин для більшості працездатного населення та є свідченням його готовності брати на себе відповідальність за результати господарювання.

У Законі України "Про соціальний захист осіб, які самостійно забезпечують себе роботою”, самозайнятість трактується як діяльність фізичних осіб (громадян, іноземців, якщо інше не встановлено міжнародними договорами, згода на чинність яких надана Верховною Радою України, та осіб без громадянства), спрямована на задоволення особистих та суспільних потреб, що здійснюється ними самостійно, на постійній або тимчасовій основі, приносить їм дохід у грошовій або іншій формі, не є працею таких осіб на підприємствах, в установах чи організаціях за трудовим договором на постійній основі чи за сумісництвом, а також не є підприємництвом відповідно до Господарського кодексу України. Згідно із цим Законом, “самозайнята особа - це будь-яка фізична особа, яка самостійно забезпечує себе роботою відповідно до умов цього Закону” [3].

Діяльність держави, спрямована на сприяння зайнятості безробітних громадян через підтримку підприємницької ініціативи і орієнтацію на організацію самозайнятості, 
є одним із перспективних шляхів активної політики на ринку праці. Як свідчить досвід багатьох східноєвропейських країн, зокрема Угорщини, Польщі, самозайнятість і мікропідприємництво позитивно впливають на загальну економічну ситуацію, досить ефективно сприяють вирішенню проблем вимушеної незайнятості в умовах перехідного періоду будь-якого суспільства.

Підвищений інтерес до становлення різних форм самостійної трудової діяльності зумовлюється, на наш погляд, такими обставинами:

- розвиток індивідуального підприємництва створює реальні умови для здійснення глибоких структурних змін у формуванні і розвитку динамічного ринкового сектора економіки;

- значною мірою знімається соціальна напруга на ринку праці, оскільки розширюється сфера прикладання праці, формується ефективна регіональна система зайнятості, що враховує соціально-психологічні, демоекономічні характеристики соціально-трудового потенціалу;

- залежно від кон'юнктури попиту та пропозиції робочої сили на регіональному ринку праці, через різні форми самозайнятості може бути досягнута продуктивна зайнятість економічно активного населення.

Наведені аргументи зумовлюють потребу в поглибленні досліджень соціальноекономічної природи самостійної трудової діяльності.

Переваги самозайнятості полягають у тому, що людина сама стає господарем своєї долі. Це дає їй можливість працювати з тими людьми, які їй до вподоби, планувати робочий час на власний розсуд, проявляти ініціативу і творчість у трудовій діяльності, цілеспрямовано підвищувати рівень своєї кваліфікації. Самозайняті особи самі створюють умови для роботи, на свій розсуд розпоряджаються доходами.

На таких засадах у суспільстві поступово формується принципово новий прошарок економічно активного населення (що є природною реакцією на трансформаційні процеси), для якого характерна зміна мотивації трудової діяльності в площині зростання тих складових процесу праці, які забезпечують реалізацію не тільки матеріальних, але й духовних потреб: задоволення від самої праці, іiї соціальної значимості, складності тощо.

У сучасній вітчизняній соціологічній літературі ще донедавна були практично відсутні грунтовні наукові дослідження феномену “самозайнятість”. Самозайняті як категорія економічно активного населення України вперше були розглянуті статистиками в 1999 р. За визначенням Держкомстату України, самозайняті - це особи, які здійснюють трудову діяльність на самостійних засадах (без залучення постійних найманих працівників), своїм власним коштом, володіють засобами виробництва i несуть відповідальність за вироблену продукцію (надані послуги). Сектор самостійної зайнятості включає працюючих не за наймом, які, на відміну від найманих працівників, самостійно організовують свою трудову діяльність на базі організації та ведення господарської діяльності, фізичних або юридичних осіб, які відповідають за результативність та ефективність цієї діяльності, а також за виконання зобов’язань по відношенню до інших осіб, зокрема в частині виконання умов трудових договорів 3 найманими працівниками тощо. До таких осіб належать: роботодавці, самозайняті, безкоштовно працюючі члени сім'ї [4, с. 14]. 
Самозайнятість як соціальне та економічне явище вперше почав вивчати на початку 1960-х рр. американський економіст Д. Філіпс. Хвилі піднесення чи спаду такого соціально-економічного феномену, як самозайнятість, є характерними практично для кожної економічної системи. Цей феномен відображає стан економіки та форми зайнятості в кожній окремій країні. Вагомий внесок у дослідження самозайнятості внесли такі американські вчені: економіст Р. Аронсон (R. Aronson) та соціолог Е. Райт (E.Wright). Саме Е. Райт наприкінці 1980-х рр. указував на обмаль досліджень із загальної проблеми самозайнятості, тоді як існує значно більше досліджень з різних видів професійної діяльності, які аж ніяк не варто ототожнювати 3 самозайнятістю [5, с. 118]. Тому, на нашу думку, питання теоретико-методологічного осмислення різних аспектів цієї проблематики є досить актуальним у ракурсі формування конкурентоспроможної економіки України.

Поширення самозяйнятості характеризується появою нових малих підприємств, які створювалися переважно в галузях із невисокою капіталомісткістю через брак капіталів - у сфері споживчих та виробничих послуг, на транспорті, в будівництві та ремонті, обслуговуючи переважно місцеві ринки. Деякі неформальні види діяльності доперебудовного періоду за нових економічних умов були легалізовані. Інші фірми виникли як незалежні підприємства в процесі реорганізації великих державних підприємств (у зв’язку з їх приватизацією, поділом, закриттям тощо) або як цілком нові утворення. Стимулом розвитку малого підприємництва була так звана мала приватизація (магазини, готелі, ресторани, перукарні, невеликі виробничі одиниці), а в окремих країнах і реституція - повернення націоналізованої власності їі колишнім власникам або спадкоємцям, що полегшувало доступ дрібним підприємцям до недорогих приміщень, обладнання, кредитів, ринків тощо.

Самозайнятість - це результат двох процесів: по-перше, розвитку ініціативи, а по-друге - зміни соціально-економічних обставин. Зміна соціальної ситуації й системи ціннісних орієнтацій особистості за нових умов призводить до зміни поведінкової активності. Як суспільство загалом, так і кожна людина потрапляють у ситуацію адаптації. Як правило, в умовах трансформаційних змін суспільства поведінку особистості формують і спрямовують не лише орієнтації й очікування людей, а й життєві ситуації. Людина зазнає впливу особистісних настанов і стереотипів, що зумовлюють її погляд на ситуацію і тим самим спонукають її до тої чи іншої поведінкової стратегії.

Самозайнятість у вигляді човникарства та примітивної торгівлі в українському суспільстві 1990-х рр. стала поширеною трудовою діяльністю. Починаючи з 1992 р. самозайнятість в Україні почала розвиватися прискореними темпами, а вже у 1998 p. чисельність самозайнятих (переважно в особистому підсобному сільському господарстві) перевищила чисельність зайнятих у промисловості.

На основі різноманітних форм власності формується гама різних організаційногосподарських різновидів виробництва, включаючи і самозайнятість. Як наслідок, формується ефективна система зайнятості, розширюється сфера прикладання праці, а отже й більше стає можливостей для самореалізації кожної людини у сфері праці. Основою самостійної зайнятості, їі несучою конструкцією є приватна власність на 
засоби виробництва. На засадах приватної власності індивід отримує простір і свободу вибору життєвої перспективи, розкриття і вдосконалення своїх здібностей, а це означає, що відбувається всебічний і вільний розвиток трудового потенціалу, продуктивних сил суспільства.

Суспільне виробництво здійснюється для потреб людей та їх розвитку. Мета розвитку виробництва в умовах приватної власності на засоби виробництва об'єктивно збігається з потребами кожного члена суспільства, у зв'язку з чим приватний власник стає зацікавленим у сенсі своєї праці, професійному характері своєї діяльності.

Розвиток приватної власності, на основі якої формуються різноманітні форми самоорганізації трудової діяльності, суттєво розширює межі суспільного поділу праці. Поглиблення суспільного поділу праці виступає об'єктивною основою різноманітності суспільних потреб та необхідності їх задоволення. Розвиток потреб суспільства обумовлює виникнення нових типів і різновидів праці, форм її організації, що, у свою чергу, змінює кількісні пропорції суспільної праці між видами діяльності та галузями виробництва.

Отже, самозайнятими будемо вважати тих, хто працює за свій власний кошт, самостійно організовує свою роботу, володіє засобами виробництва та несе відповідальність за вироблену продукцію (якість, ціну, збут тощо).

У питанні визначення самозайнятості з метою правильного подальшого вибору показників статистичного вимірювання дослідники-економісти застосовують два підходи:

• звужений, коли йдеться про тих, хто працює одноосібно, без залучення інших працівників, на будь-якій (оплатній чи безоплатній) основі;

- розширений, пов'язаний з індивідуальною трудовою діяльністю на мікропідприємстві з чисельністю працюючих до п'яти осіб [6, с. 5].

Згідно з методикою Міжнародної організації праці (МОП): “До сектора самозайнятості входять усі особи, що працюють у господарських одиницях, які належать і керовані самостійно зайнятою особою, тому сектор самостійної зайнятості включає працюючих самостійно, не за наймом, працівників, працюючих власників і всіх працівників, тобто постійних і тимчасових працівників, учнів і безоплатно працюючих членів сім’ї, в тому числі і членів виробничих кооперативів” [7].

На думку відомого вітчизняного вченого Е. Лібанової, самозайнятими варто вважати тих осіб, які здійснюють трудову діяльність на самостійній основі (без залучення постійних найманих працівників), на свій власний кошт, володіють засобами виробництва і несуть відповідальність за вироблену продукцію (надані послуги) [2, с. 213]. М. Пітюлич до самозайнятих осіб відносить роботодавців (працюючих власників), зайнятих індивідуальною трудовою діяльністю та безоплатно працюючих членів сім'ї, включаючи членів виробничих кооперативів [8, с. 89].

Дещо іншої думки стосовно самозайнятих дотримуються російські соціологи. Вони вважають, що самозайнятих - власників індивідуального та сімейного бізнесу, що працюють не за наймом і переважно поодинці, можна було б назвати зайнятими індивідуальним підприємництвом, які працюють самостійно на безконтрактних засадах, проте переважно не сприймають свій статус зайнятості як статус підприємця 
[9, с. 23]. На думку російського соціолога Т. Заславської, основною відмінністю самозайнятих від “класичних" підприємців є індивідуальний тип праці, відносно невеликий обсяг їхнього бізнесу, а також “відсутність у ньому компоненти, що пов'язана з організацією спільної діяльності людей” [10, с. 4].

На думку російського вченого Б. Бреєва, до самозайнятих варто віднести підприємців, осіб, працюючих не за наймом, членів виробничих кооперативів і неоплачуваних працівників сімейних підприємств [11, с. 189].

У Російській Федерації, згідно із законом про зайнятість, до осіб, які самостійно забезпечують себе роботою, відносять: підприємців; осіб, зайнятих індивідуальною трудовою діяльністю, включаючи фермерів, а також членів виробничих кооперативів [12].

Під самозайнятістю Р. Аронсон розумів альтернативний спосіб заробітку для проживання через продаж власної праці [13]. Натомість Е. Райт зазначав, що самозайнята особа заробляє кошти завдяки своїй праці, причому не продаючи її роботодавцю за заробітну плату. Визначаючи соціальну позицію самозайнятих, Е. Райт, один із найавторитетніших спеціалістів з питань соціально-класового аналізу американського суспільства, характеризує їх як таких, що мають власні засоби виробництва й нікого не наймають. Він відносить самозайнятих до одного з трьох основних класів капіталістичного суспільства - до малої буржуазії (petty bourgeoisie), тим самим підкреслює відмінність їх як класу від двох інших - класу капіталістів, що володіють засобами виробництва й наймають робітників, і класу робітників, які не мають засобів виробництва і продають свою робочу силу капіталістам [5, с. 17].

Феномен “самозайнятість” набуває більш вираженого соціологічного контексту у соціально-класових схемах, побудованих на методологічних підходах Е. Райта й Дж. Голдторпа. Згідно з позицією Дж. Голдторпа, самозайнятих характеризує наявність певної кількості капіталу та, свого роду, свобода від прямого нагляду за виконанням ними робочих завдань [14, с. 41]. Доцільно зауважити, що в питанні визначення самозайнятих як Е. Райт, так і Дж. Голдторп виокремлюють такі ключові характеристики даної категорії: наявність власних засобів виробництва й автономність трудового процесу.

Цього підходу дотримується О. Іващенко, яка вважає, що з соціологічної точки зору, самозайнятість - це індивідуальна трудова діяльність у сферах дрібного виробництва та послуг, що здійснюється на основі власних засобів виробництва за наявності автономії й відсутності організаційного контролю в трудовому процесі та без застосування найманої праці [15, с. 194].

Як тип економічної поведінки самозайнятість здійснюється за відповідними принципами, основними з яких є економічна самостійність, економічна відповідальність, свобода вибору тощо.

Економічна самостійність означає те, що той чи інший вид діяльності об’єднує в одній особі як власника, так і працівника, і керівника. Тобто всі рішення щодо організації діяльності приймає одна особа, яка об'єднує в собі ці три зазначені ознаки. Щодо економічної відповідальності, то тут слід наголосити, що відповідальність за прийняті рішення, а також за результати діяльності поєднується в одній особі.

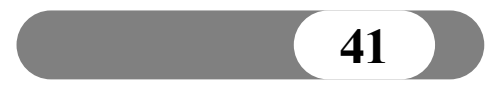




\section{СОЦІОЛОГІЯ}

Економічна свобода вибору діяльності самозайнятих означає, що індивід, який бажає зайнятись підприємництвом, може на власний розсуд вибирати вид та форму трудової діяльності [16, с. 90-91].

Різновиди та форми самостійної зайнятості можна класифікувати за певними ознаками, а саме:

- формальністю;

- легальністю;

- галузями народного господарства;

- місцем у формуванні суспільного продукту;

- просторовими межами;

- джерелами залучення початкового капіталу;

- регулярністю здійснення діяльності;

- формою отримання прибутку тощо.

Виходячи із ознаки формальності, виділяють зареєстрованих і незареєстрованих самозайнятих. Субстанцію других, як правило, становлять власники особистих підсобних господарств, люди вільних професій, деякі фермери та ін. До перших, тобто зареєстрованих самозайнятих, можна віднести, насамперед, осіб інтелектуальної сфери - адвокатів, нотаріусів, архітекторів, естрадних артистів, фермерів, частину вуличних підприємців та ін.

Формальний і неформальний сектори у сфері самостійної зайнятості виділяють такі вчені, як Р. Кузнєцова, О. Карнаухова, Л. Шевченко [17, с. 96]. Цілком очевидно, що підставою для такої градації є масштабний тіньовий сектор, що склався в економіці України. Однак дискусійним є питання про віднесення до неформального сектора зайнятих продажем товарів, ремонтом побутової техніки, ремонтом автомобілів, репетиторством, перевезеннями, економічним туризмом тощо, оскільки критерієм віднесення до певного сектора $є$ не сам вид діяльності, а умови, за яких вона здійснюється. Аналізуючи неформальну зайнятість у нерегламентованому секторі, варто підкреслити, що саме цей сектор створює реальні умови для розвитку підприємницької ініціативи й отримання більш високих прибутків, а для окремих категорій населення він є єдиною можливістю забезпечити своє майбутнє.

Наступною класифікаційною ознакою є легальність, залежно від якої самозайнятість може бути легальною або нелегальною. Всі різновиди самостійної зайнятості, які не суперечать діючому законодавству країни (зареєстрована вулична торгівля, фермерські господарства тощо), належать до легальної самозайнятості. Натомість до нелегальних слід віднести тих самозайнятих, які займаються нелегальним перевезенням товарів через кордон, нелегальним продажем зброї, наркотиків, алкогольних напоїв тощо. Принагідно зауважимо, що такі самозайняті функціонують у сфері тіньової економіки, оскільки вони ніде не зареєстровані, а відповідно і не сплачують податків.

Самозайнятість можна класифікувати і за галузями народного господарства, а саме: самозайняті у сільському господарстві, у торгівлі, у сфері охорони здоров'я та в інших галузях.

За місцем у формуванні суспільного продукту можна виділити ще два види самозайнятості. Відповідно до зазначеної класифікації самозайнятість можна 
класифікувати як виробничу (самозайняті у сфері матеріального виробництва), так і невиробничу (самозайняті у сфері послуг).

За просторовою ознакою виділяють самозайнятих, які працюють у сільській місцевості й у містах.

Щодо джерел залучення початкового капіталу для ведення власної справи, то самозайнятих можна класифікувати на тих, які здійснюють свою діяльність за рахунок власних коштів; коштів, позичених у банківських та небанківських установах (комерційні банки, центри зайнятості, які можуть надавати кредити у вигляді одноразової виплати допомоги по безробіттю та інше); допомоги членів сім'ї, родичів.

Залежно від регулярності здійснення діяльності можна виділити самозайнятих, які займаються власним бізнесом постійно, сезонно, випадково, тимчасово. До постійно зайнятих можна віднести тих самозайнятих, які здійснюють свою діяльність регулярно (приватні лікарі, фермери тощо), сезонно зайняті - ті, діяльність яких, як правило, припадає на один і той же період року (тракторист із власним транспортом; самозайняті, які вирощують на власних ділянках сільськогосподарську продукцію, тощо). Випадково самозайнятими вважаються особи, які здійснюють свою діяльність лише тоді, коли існує на неї попит. Як правило, випадкова самозайнятість за своєю природою є формою отримання додаткового заробітку на тлі формування подвійної зайнятості. Подібне трактування має і тимчасова самозайнятість. Сюди можна віднести осіб, які не мають тимчасово постійного місця роботи і вимушені займатися впродовж певного періоду часу самостійною діяльністю.

Беручи за основу класифікації форму отримання прибутку, можна виділити тих самозайнятих, які отримують грошовий дохід та дохід у натуральному вигляді (у вигляді одержаного врожаю, використаного на власне споживання тощо). Як правило, отримують дохід у натуральному вигляді ті самозайняті, які здійснюють свою діяльність у сфері сільськогосподарського виробництва. А всі інші самозайняті, такі як приватні нотаріуси, лікарі, адвокати, спортсмени тощо, отримують свій дохід у грошовій формі.

На нашу думку, доцільним є розмежувати поняття “традиційна зайнятість” і “самозайнятість”. Самозайнятість від традиційної зайнятості з регулярною винагородою відрізняється властивою їй автономністю й індивідуальною спрямованістю в трудовому процесі, підконтрольністю лише собі й кон'юнктурі ринку товарів і послуг [15, с. 194].

На сьогодні в Україні вже є напрацьовані схеми розвитку самозайнятості та малого підприємництва, які реалізуються Державною службою зайнятості. Так, у рамках реалізації Угоди Уряду України, ПРООН і МОП "Впровадження гнучких програм професійного навчання для безробітних” передбачено підпроект щодо розвитку малого підприємництва та самозайнятості населення [18, с. 90].

Аналіз соціально-економічної ефективності самозайнятості показує, що їі активна підтримка з боку регіональних органів управління здатна значною мірою стабілізувати ситуацію на локальних ринках праці, нівелювати безробіття, відкрити простір для самореалізації економічно активного населення. Від самого початку економічних трансформацій самозайнятість асоціюється 3 активністю населення, 
відмовою від патерналізму в суспільних відносинах, зниженням безробіття. В ідеалі самозайнятість дає людині значну свободу дій, можливість проявити себе й отримувати доходи відповідно до кількості й якості затраченої фізичної і розумової праці, комерційного ризику і вкладеного капіталу.

Проте реальний стан справ із самозайнятістю в Україні далекий від відповідності рекомендаціям МОП. Ряд проблем на сьогодні залишається практично не вирішеними.

По-перше, не враховується той факт, що, скажімо, застійні безробітні навряд чи здатні самостійно працювати в сучасних складних умовах без спеціальних додаткових заходів сприяння.

По-друге, відсутнє ефективне регулювання (на ринкових засадах, але з обов'язковим врахуванням соціальної значимості тих чи інших галузей та виробництв) місцевою владою вибору сфери (галузі) започаткування власної справи;

По-третє, не диференційовано підхід, а отже й дії державної служби зайнятості стосовно безробітних, які (за ії сприяння чи самостійно) відкрили власну справу (на умовах самозайнятості чи із залученням найманої праці) і збанкрутували [18].

Вільно обрана форма зайнятості як орієнтир соціально-ринкової економіки $€$ одним із домінуючих принципів, на якому повинні будуватися державна політика і механізм забезпечення продуктивної зайнятості. Важливими передумовами реалізації цього принципу має бути сприяння розвиткові всіх форм власності і господарської діяльності з метою розширення можливостей вибору економічно активним населенням сфери застосування праці.

Отже, здійснення активної політики зайнятості в напрямі розвитку самозайнятості неможливе без ліквідації адміністративних перешкод і створення сприятливого економічного середовища. Складові бажаної політики стосовно самозайнятості в доповіді Міжнародного бюро праці формулюються таким чином:

- відсутність дискримінації стосовно цього виду діяльності;

- селективна допомога, спрямована на усунення дисбалансів і нерівності можливостей - з одного боку, і на витіснення неефективних, небажаних суспільству форм самозайнятості - з другого;

- рівноправність і однакова з найманими працівниками доступність соціального забезпечення;

- створення спеціальних органів для представництва і захисту інтересів самозайнятих [2, с. 346].

Підсумовуючи вищевикладене, можна констатувати, що самозайнятість - це свого роду, сполучна ланка між досягненням економічного зростання і створенням можливостей для розвитку людини. Трансформаційні зміни, які відбуваються в сучасному українському суспільстві, формування інституціональної мережі соціальноринкової економіки супроводжуються зміною традиційних форм зайнятості та уявлень щодо іï сутності. Все це в сукупності вимагає подальших наукових пошуків, розробки нових, нетрадиційних підходів до вивчення зайнятості, формування активнодіяльної та ініціативної особистості. Оскільки динамічна економіка вимагає активної поведінки людини та її розвитку, то саме від цього великою мірою залежить розвиток самостійної зайнятості. 
Державна політика щодо підтримки самозайнятості буде ефективною лише за умови налагодження повноцінного інформаційного забезпечення цієї справи, глибокого усвідомлення її значення у вирішенні проблем безробіття, а також як важливого чинника економічного піднесення країни.

1. Онікієнко В.В. зайнятість та якість життя населення // Укр. соціум. - 2002. - № 1. C.111-121.

2. Лібанова Е. Ринок праці та соціальний захист: Навч. посіб. із соц. політики / Е. Лібанова, О. Палій. - К.: Вид-во Соломії Павличко “Основи”, 2004. - 491 с.

3. Закон України "Про соціальний захист осіб, які самостійно забезпечують себе роботою"

4. Економічна активність населення Львівської області у 2006 році: Стат. Зб. // Гол. управління статистики у Львівській обл.: 2007 - № 07-55/359 - 94 с.

5. Wright E. Class Counts. Comparative Studies in Class Analysis. - Cambridge, 1997. - C. 118.

6. Позняк О. Теоретико-методологічні основи дослідження самозайнятості в Україні //Україна: аспекти праці. - 2000. - № 8. - С. 3-8.

7. Содействие самозанятости: Доклад 7 // Международная организация труда. Сессия 77. Женева.: МОТ, 1990. - 214 с.

8. Пітюлии М., Пітюлии М. (мол.). Фінансово-економічні механізми стимулювання розвитку самостійної зайнятості населення // Регіональна економіка. - 2003. - № 4. - С. 88-93.

9. Занятость и поведение домохозяйств: адаптация к условиям перехода к рыночной экономике в России / Под ред. С. Кларка. - М., 1999. - С. 23

10. Заславская T. Бизнес-слой российского общества: сущность, структура, статус // Социол. исслед. - 1995. - № 3. - С. 3-12.

11. Бреев Б.Д. Безработица и некоторые пути ее минимизации // Демографія та соціальна економіка. - 2004. - № 1-2. - С. 189-197.

12. Закон “О занятости населения в РСФСР” // Советская Россия. - 1991. - 18 мая.

13. Aronson R. Self-Employment: a Labour Market Perspective. - Ithaca, 1991. - C. xi.

14. Goldthorpe J.H. Social Mobility and Class Structure in Modern Britian. - Oxford, 1980. - C. 41.

15. Іващенко O. Соціологія самозайнятості: до проблеми визначення предмета // Соціологія: теорія, методи, маркетинг. - 2002. - № 4. - С. 189-196.

16. Пітюлич $M$. Теоретичні основи розвитку самостійної зайнятості // Регіональна економіка. - 2003. - № 3. - C. 89-95.

17. Кузнєиова Р.П. Карнаухова О.В., Шевченко Л.В. Теоретичні основи самостійної зайнятості населення як одного з напрямів зниження безробіття // Зайнятість та ринок праці . - Вип. 4. - К.: НЦ ЗРП, 1996. - С. 95-99.

18. Інтеграція молоді в сучасні економічні відносини: Щорічна доповідь Президентові України, Верховній Раді України, Кабінету Міністрів України про становище молоді в Україні (за підсумками 2000 року). - К.: Укр. ін-т. соціол. дослідж., 2001. - 166 с. 